\title{
Evaluation and Monitoring of Concrete Submitted to Microbially-Induced Deterioration
}

\author{
Mavi Umeres, Civil Engineer ${ }^{1}$, Mauricio Chavez, Civil Engineer ${ }^{1}$, Sandra Rodriguez, Civil Engineer ${ }^{1}$ and Elsa \\ Carrera, Civil Engineer ${ }^{1}$ \\ ${ }^{1}$ Universidad Peruana de Ciencias Aplicadas, Perú,u201311802@upc.edu.pe,u201310798@upc.edu.pe, \\ Sandra.rodriguez@upc.edu.pe,pcciecar@upc.edu.pe
}

\begin{abstract}
Concrete corrosion is one of the main problems of degradation and loss of functionality that can derive into a partial or total collapse of a structure. Each time concrete gets in touch with residual water, water runoffs, or acid drainage in mines, there exists a process denominated Induced Microbial Corrosion, which is caused by sulfurizing bacteria, which generates sulfuric acid too as part of their metabolism. This investigation contemplates the evaluation and monitoring of concrete designs, in which there are study variables associated, for example, water/cement relationship, Filler Calizo addition mineral. This experimental study analyzes: (a) Effectiveness of the proposed additive through a microbiological test, (b) concrete properties in a hard state through destructive and non-destructive laboratory tests, and (c) Concrete resistance to sulfuric acid concentrations. The principal discovery in this investigation concludes with the recommendation of a design of a mixture that inhibits the bacterial growth and reduces the concrete deterioration submitted to sulfuric acid.
\end{abstract}

Keywords-- Corrosion, biodeterioration, sulfuric acid, antimicrobial additive, durability.

\section{INTRODUCTION}

Materials biodeterioration on structures exposed to residual water contact, acid drainages on mines and runoff water, have been recently recognized as an important deterioration mechanism, which can be classified by the material effect such: mechanical or physical rupture, aesthetic deterioration and among the most important is the chemical involvement because it is directly related to the microbial attack and is produced when the sulfur bacteria use concrete components as a growth substrate, or excrete harmful products like the sulfuric acid, which harms the material and its intern structure, this attack threatens durability and materials quality, so this represents a serious problem and its effects provoke thousands of millions of dollars per year [1].

Because of this issue, it shows an idea: to incorporate an additive that can inhibit bacteria growth and reproduction on aggressive environments described a few lines before. There are some researches about the long-term utility, effectiveness, and behavior of the additive on concrete mixtures, for example, Bell et al. (1999) performed two tests to demonstrate the effectiveness of an antibacterial concrete, create through the inclusion of an antimicrobial additive, versus a generic additive; on the first place, both concretes were submitted to a bacterial suspension on their surface for about 24 hours, the results demonstrated that the antibacterial concrete eliminated the bacteria on a $100 \%$ of effectiveness and inhibited their microscopic growth; on the second place, both concrete were submitted to a sewer system for 3 months long, the results demonstrated that the weight difference on a normal concrete was 30.6 grams, and the tested concrete was 2.9 grams, which demonstrates a remarkable diminution on its corrosion [2].

A research was done by Ramsburg (2004) in the USA about the antibacterial concrete application because $40 \%$ of 20,000 residual water systems are conformed by concrete pipelines which are attacked by corrosion causing a premature replacement of failed structures. So, the ideal method to fight this corrosion made by Biogenic Sulfuric Acid and to affect permanently the bacterial growth cells was the application of an antimicrobial agent to the concrete mixture. The author mentions that this concrete has been evaluated for about 6 years with successful field and laboratory tests to determine the bacteria colonization in the material, which entails to awake the interest of the big industries to apply this antibacterial concrete on prefabricated elements, in which there was made an extensive test program that consisted on the fabrication of 12 prefabricated concrete with and without the microbial agent, the results demonstrated that the antibacterial concrete is effective to prevent not only the growth of sulfur bacteria but of a lot of microorganisms that are alive on aggressive environments too [3].

As mentioned above, each time it is more essential the application of actions against the microbial corrosion effects induced in concrete structures of recollection systems and residual water treatments. Currently, the centralism in Peru has been reflected in the uncontrolled growth of the population in the capital city, so that has a direct relationship with the treatment and operation of water and sewerage public services. Lima and Callao habitants generate about 550 millions of $\mathrm{m}^{3}$ of residual water per year, which are recollected by secondary sewerage networks $(11,643 \mathrm{~km}$ with diameter not much than $350 \mathrm{~mm}$ ) and are driven through primary collectors networks (918 km with diameter between $350 \mathrm{~mm}$ to $2400 \mathrm{~mm}$ ) which are taken from 22 Treatment Residual Water plants (PTAR) [4], structures that are exposed directly to the mentioned problematic. Thus, it is evident the importance of inhibit permanently the bacterial cell growth through the antibacterial concrete application, to avoid the sulfuric acid production and concrete biodeterioration.

\section{METHODOLOGY}

The following investigation is an experimental type. There are evaluation and monitoring through laboratory tests on

\footnotetext{
Digital Object Identifier (DOI):

http://dx.doi.org/10.18687/LACCEI2020.1.1.367

ISBN: 978-958-52071-4-1 ISSN: 2414-6390
} 
different concrete designs, from which some study variables are defined, for example, water/cement, Filler Calizo mineral addition percentage, and Antimicrobial Additive dosification. Effectiveness is determined for the mentioned additive through a microbiological test and then, concrete properties are evaluated through hard state tests and its resistance to sulfuric acid concentrations. Then, it comes to the explanation of the investigation development.

On the first place, the physical properties of materials used to design the concrete mixture (water, cement, additives, and other additions) are defined. About the Antimicrobial Additive, this has the name of MasterLife AMA 100, which is going to join molecularly to the hydration components of the cement and destroys the cellular membrane of aerobic bacteria through and electrophysical mechanism [5].

Likewise, in reference to the aggregates, there were executed granulometry tests according to the NTP 400.012:2013 [6], specific weight and absorption according to la NTP 400.022:2013 [7] for fine aggregates and NTP 400.021:2013 [8] for thick aggregates, moisture content according to NTP 339.815:2013 [9], and unit weight according to NTP 400.017:2011 [10], intending to obey to the minimum quality standard and to have the obtained parameters in an optimal condition so that the mixture design could be done without altering the concrete properties in both fresh and hard states.

The mixture design is done through the methodology established by the committee ACI 211.1 [11] because it is one of the most popular and mostly used in this mixture of materials to obtain and mix the concrete.

There are two mixtures design groups proposed; the first is elaborated to do a microbiological test, conformed by a patterned concrete (P-I) and 3 more antibacterial concretes (D-I a D-III) in which the investigation variable was the Antimicrobial Additive dosification; the second was design to evaluate concrete properties on hard state and to do a chemical test with different sulfuric acid concentrations, conformed by a patterned concrete (P-II) and five antibacterial concretes (DIV a D-VIII) with different water/cement relationship and Filler Calizo mineral addition percentage.

For each design, there were done tests with concrete in a fresh state like settlement according to NTP 339.035:2015 [12], temperature according to NTP 339.184:2013 [13], unit weight, performance and air content according to NTP 339.046:2008 [14], and setting time according to NTP 339.082:2017 [15], the obtained results help to reset and adjust some parameter to determine the definite design of the mixture so that it would help to ensure the quality of the concrete.

Later on, the next step is to proceed with the microbiological test. In this stage, there is a simulation in the bioreactor with the same environmental conditions of a sewerage system, where residual water is on a constant runoff, so it is necessary to adequate oxygenation to provoke the bacterial growth.

For that, the air is introduced through a compressor and to avoid the entry of other unnecessary microorganisms, a filter is used too; on the bioreactor base, an air sprinkler is placed with a flow of 1 LVM (liquid volume per minute) to ensure the oxygenation and homogenization of the system. Finally, all the air entered is eliminated by an air trap. The bacterial groups of higher prevalence were: Fecal Coliforms, Sulfo Bacteria, Mesophilic Heterotroph, which belong to the effluents of the Residual Water treatment plant of Engineering National University.

Likewise, to ensure the bacterial growth, the fermentation Fed Batch method was applied, in which consists of feeding the system each 5 days with $100 \mathrm{ml}$ of nutritional broth in a double concentration supplemented with ammonium sulfate. The experimental scheme is shown in Fig. 1. The results obtained allowed to define the penetration grade of bacteria both in surface and concrete matrix and with this, to determine the Antimicrobial Additive effectiveness.

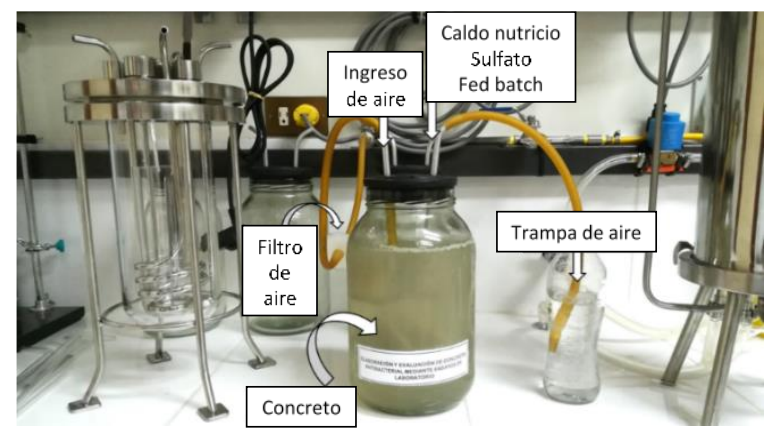

Fig. 1 Experimental scheme in the bioreactor.

Third, concrete was evaluated on its hard state in different curing ages to determine the properties and performance of it. In one hand, destructive tests were done as resistance to the compression according to ASTM C39M-18 [16], quick permeability to the chloride according to ASTM C1202-19 [17], water penetration depth under pressure according to UNE-EN 12390-8:2009 [18] and abrasion according to ASTM C944M-12 [19]; on the other hand. non-destructive tests were done as air permeability [20] and ultrasonic speed according to ASTM C597-16 [21].

Finally, a chemical test is done, in which the effect of the attack of sulfuric acid is evaluated on concrete samples. For this, there were three sulfuric acid solutions prepared with concentrations on $3 \%, 5 \%$ y $7 \%$, on which 2 design tubes were exposed for 8 weeks.

The results and performance of the exposed samples were evaluated through the weight loss through final measures (diameter, height) and visual analysis. 


\section{RESULTS}

As follows, the results obtained are detailed for each stage of the investigation.

\section{A. Microbiological Test}

The concrete samples to be evaluated correspond to the designs of the first group, which are differentiated by the amount of Antimicrobial Additive incorporated, as is shown in Table I.

TABLE I

DOSIFICATION RESULTS OF THE GROUP I DESIGN FOR $1 \mathrm{M}^{3}$

\begin{tabular}{|c|c|c|c|c|c|}
\hline \multirow{2}{*}{ Inputs } & \multirow{2}{*}{ Und } & \multicolumn{4}{|c|}{ Design codification } \\
\cline { 3 - 6 } & & $\mathrm{P}-\mathrm{I}$ & $\mathrm{D}-\mathrm{I}$ & $\mathrm{D}-\mathrm{II}$ & $\mathrm{D}-\mathrm{III}$ \\
\hline Cement type I & $\mathrm{kg}$ & 275 & 275 & 275 & 275 \\
\hline Filler & $\mathrm{kg}$ & 48 & 48 & 48 & 48 \\
\hline Water & 1 & 232 & 232 & 232 & 232 \\
\hline Sand & $\mathrm{kg}$ & 903 & 901 & 899 & 896 \\
\hline Stone Huso 67 & $\mathrm{kg}$ & 846 & 844 & 843 & 840 \\
\hline Master Set R800 & 1 & 1.49 & 1.49 & 1.49 & 1.49 \\
\hline Master Rheobuild 1201 & 1 & 3.88 & 3.88 & 3.88 & 3.88 \\
\hline Master Life AMA 100 & 1 & - & 1.26 & 2.52 & 5.03 \\
\hline Air & $\%$ & 2 & 2 & 2 & 2 \\
\hline Relation a/c & & 0.65 & 0.65 & 0.65 & 0.65 \\
\hline Unit weight & $\mathrm{Kg} / \mathrm{m}^{3}$ & 2312 & 2309 & 2307 & 2303 \\
\hline Compression resistance & $\mathrm{Kg} / \mathrm{cm}^{2}$ & 210 & 210 & 210 & 210 \\
\hline
\end{tabular}

Three stages of exposure of concrete samples corresponding to 20,30, and 40 days were evaluated. For each period the following parameters were analyzed.

1) $\mathrm{pH}$ measure: At the beginning of the experimentation the recorded $\mathrm{pH}$ was 5, which decreased by 1 for each exposure time, resulting after 40 days at a $\mathrm{pH}$ of 2 . This result is due to the loss of alkalinity of the residual water sample becoming a more acidic solution over time. This leads to a greater formation of microorganisms that cause the deterioration of concrete. Also, a decrease in $\mathrm{pH}$ influences the durability properties of the exposed samples.

2) Biofilms formation on the concrete: The Leica Stereoscope was used to verify the colonization of bacteria on the concrete. For each stage analyzed, the bioreactor system was suspended momentarily to remove a concrete block from each design.

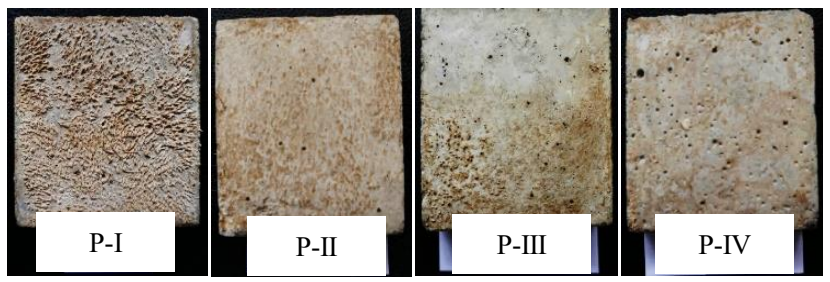

Fig. 2 Concrete samples exposed to 20 days.

First, at 20 days of exposure, all designs show bacterial growth; However, the amount of bacteria inside the bioreactor at the time analyzed is not significant in order to form biofilms on the concrete. Fig. 2 shows that all designs have a yellowish color due to the passage of bacteria and the effect of the Antimicrobial Additive is not appreciated.

Secondly, the results at 30 days of exposure are presented in Fig. 3, greater growth of bacteria in the form of biofilms on the standard concrete (P-I); that is, the amount of bacteria present in the bioreactor was increasing over time. The D-I design has a greater coloration, so the effect of the additive is not demonstrated. However, designs D-II and D-III show a low effect of the additive by having small areas without bacteria, so far, no significant effect of the Antimicrobial Additive can be seen.

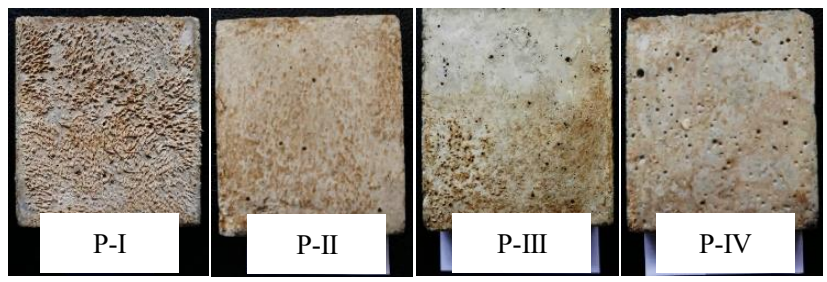

Fig. 3 Concrete samples exposed to 30 days.

Finally, the results at 40 days of exposure are presented in Fig. 4, the standard concrete (P-I) has a greater amount of biofilms that can be seen in high relief, the greatest amount of bacteria in the bioreactor is evident. For the present time of exposure, a greater effect of the Antimicrobial Additive is observed. The D-II and D-III designs that have a higher additive dosage $\left(2.52 \mathrm{l} / \mathrm{m}^{3}\right.$ and $5.03 \mathrm{l} / \mathrm{m}^{3}$, respectively) show a lower coloration and greater areas of lead color are appreciated, which means that the concrete in certain Parts is free of bacteria.

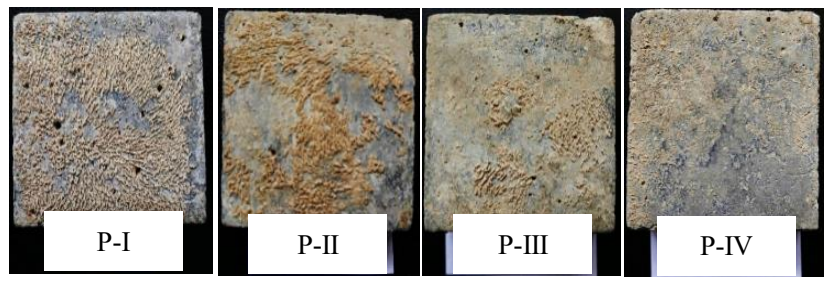

Fig. 4 Concrete simples exposed to 40 days.

According to the results obtained in the experimentation, the optimal dosage of Antimicrobial Additive is $2.52 \mathrm{1} / \mathrm{m}^{3}$ corresponding to the D-II design. It should be borne in mind that the effect of the additive decreases when mixed with the concrete components so that a wetting time in the aqueous medium is required for its activation.

\section{B. Concrete tests on hard test}

The concrete samples correspond to the designs of the second group, which present a variation in the water/cement ratio and percentage of Filler Calizo mineral addition with an established dosage of Antimicrobial Additive, as shown in Table II 
TABLE II

DOSIFICATION RESULTS OF THE GROUP II DESIGN FOR $1 \mathrm{M}^{3}$

\begin{tabular}{|l|c|l|l|l|l|l|l|}
\hline \multirow{2}{*}{\multicolumn{1}{c|}{ Inputs }} & \multirow{2}{*}{ Und } & \multicolumn{6}{|c|}{ Design codification } \\
\cline { 3 - 8 } & & P-II & $\begin{array}{c}\text { D- } \\
\text { IV }\end{array}$ & D-V & P-II & $\begin{array}{c}\text { D- } \\
\text { VII }\end{array}$ & $\begin{array}{c}\text { D- } \\
\text { VIII }\end{array}$ \\
\hline Cement type I & $\mathrm{kg}$ & 275 & 397 & 357 & 325 & 291 & 258 \\
\hline Filler & $\mathrm{kg}$ & 48 & 70 & 63 & 57 & 32 & 65 \\
\hline Water & $\mathrm{lt}$ & 232 & 231 & 231 & 232 & 232 & 232 \\
\hline Sand & $\mathrm{kg}$ & 902 & 831 & 853 & 873 & 900 & 897 \\
\hline Stone Huso 67 & $\mathrm{kg}$ & 846 & 779 & 800 & 818 & 843 & 840 \\
\hline $\begin{array}{l}\text { Master Set } \\
\text { R800 }\end{array}$ & 1 & 1.49 & 2.15 & 1.93 & 1.76 & 1.49 & 1.49 \\
\hline $\begin{array}{l}\text { Master } \\
\begin{array}{l}\text { Rheobuild } \\
\text { 1201 }\end{array}\end{array}$ & 1 & 4.26 & 6.72 & 5.80 & 3.78 & 4.26 & 5.23 \\
\hline $\begin{array}{l}\text { Master Life } \\
\text { AMA 100 }\end{array}$ & 1 & - & 2.52 & 2.52 & 2.52 & 2.52 & 2.52 \\
\hline Air & $\%$ & 2 & 2 & 2 & 2 & 2 & 2 \\
\hline Relation a/c & & 0.65 & 0.45 & 0.50 & 0.55 & 0.65 & 0.65 \\
\hline Unit Weight & $\mathrm{Kg} / \mathrm{m}^{3}$ & 2311 & 2321 & 2316 & 2314 & 2309 & 2304 \\
\hline $\begin{array}{l}\text { Compression } \\
\text { resistance }\end{array}$ & $\mathrm{Kg} / \mathrm{cm}^{2}$ & 210 & 210 & 210 & 210 & 210 & 210 \\
\hline
\end{tabular}

On the one hand, the tests performed on the destructive hardened concrete mixture are: compressive strength, rapid chloride permeability, water penetration depth under pressure and abrasion, the results are shown in Table III and Table IV.

TABLE III

DESTRUCTIVE TESTS RESULTS- PART I

\begin{tabular}{|c|c|c|c|c|c|c|c|c|}
\hline \multirow{2}{*}{ Design } & \multicolumn{7}{|c|}{ Compression resistance } & \multicolumn{2}{|c|}{ Chloride rapid permeability } \\
\cline { 2 - 10 } & 1 & 3 & 7 & 14 & 28 & 90 & $\begin{array}{c}\text { Coulombs } \\
\text { (A.s) }\end{array}$ & Permeability \\
\hline P-II & 48 & 176 & 271 & 282 & 311 & 320 & 2561 & Moderated \\
\hline D-IV & 104 & 260 & 357 & 369 & 390 & 412 & 1828 & Low \\
\hline D-V & 85 & 210 & 314 & 331 & 358 & 371 & 1958 & Low \\
\hline D-VI & 79 & 195 & 269 & 284 & 334 & 342 & 2237 & Moderated \\
\hline D-VII & 51 & 189 & 269 & 271 & 332 & 339 & 2690 & Moderated \\
\hline D-VIII & 47 & 185 & 237 & 249 & 298 & 310 & 2771 & Moderated \\
\hline
\end{tabular}

TABLE IV

DESTRUCTIVE TESTS RESULTS - PART II

\begin{tabular}{|c|c|c|}
\hline \multirow{3}{*}{ Design } & Water permeability & Abrasion \\
\cline { 2 - 3 } & Penetration depth $(\mathrm{mm})$ & Usage depth $(\mathrm{mm})$ \\
\hline P-II & 34 & 0.89 \\
\hline D-IV & 24 & 0.66 \\
\hline D-V & 31 & 0.71 \\
\hline D-VI & 33 & 0.81 \\
\hline D-VII & 32 & 0.82 \\
\hline D-VIII & 29 & 0.84 \\
\hline
\end{tabular}

The designs that present better properties in the hardened state are D-IV, D-V, and D-VIII.

Regarding the compressive strength, all designs have an $f^{\prime} \mathrm{c}$ greater than $210 \mathrm{~kg} / \mathrm{cm}^{2}$ after 7 days of curing in the well, the D-IV, and DV designs have a better result due to their low water/cement ratios. On the other hand, the D-VIII design, having the highest content of Filler Calizo in cement replacement, presents the least resistance among all designs.
The results obtained from the Fast Chloride Permeability show that the D-IV and D-V designs have low permeability, while the D-VIII design has a greater loading step with moderate permeability, due to its important Filler content. It should be borne in mind that the test indicates the movement of all ions present in the concrete and may vary according to the additions incorporated.

The maximum penetration depth, obtained from the water permeability test, is acceptable for designs with values less than the minimum covering of $40 \mathrm{~mm}$, established for pipes and connections exposed to the weather by the E060 Reinforced Concrete guideline [22]. The D-VIII design has one of the lowest penetrations, which shows that the Filler mineral addition works as an optimal material for permeability. On the other hand, the concrete presents a higher penetration as the water/cement ratio increases as shown in designs D-IV and D-V.

Finally, the results of the abrasion test resemble those of compressive strength, in which designs with a lower water/cement ratio (D-IV and D-V) are the most prominent in terms of surface wear resistance. Concerning the D-VIII design, it shows less wear compared to the P-II standard design, so Filler mineral addition is considered to provide cohesion and hardening properties between paste and aggregates.

On the other hand, the non-destructive hardened state tests are air permeability and ultrasonic pulse rate, the results are shown in Table V.

TABLE V

NON-DESTRUCTIVE TEST RESULTS

\begin{tabular}{|c|c|c|c|c|c|}
\hline \multirow{3}{*}{ Design } & \multicolumn{3}{|c|}{ Air permeability } & \multicolumn{2}{|c|}{ Ultrasonic Pulse Velocity } \\
\hline & \multicolumn{2}{|c|}{$\mathrm{kT}\left(10^{-16} \mathrm{~m}^{2}\right)$} & \multirow[b]{2}{*}{ Quality } & \multirow{2}{*}{$\begin{array}{l}\text { Wave velocity } \\
(\mathrm{m} / \mathrm{s})\end{array}$} & \multirow{2}{*}{$\begin{array}{r}\text { Concrete } \\
\text { quality }\end{array}$} \\
\hline & $\begin{array}{c}7 \\
\text { days }\end{array}$ & $\begin{array}{c}28 \\
\text { days }\end{array}$ & & & \\
\hline P-II & 0.028 & 0.009 & Excellent & 4305 & Good \\
\hline D-IV & 0.005 & 0.003 & Excellent & 4441 & Good \\
\hline $\mathrm{D}-\mathrm{V}$ & 0.008 & 0.005 & Excellent & 4387 & Good \\
\hline D-VI & 0.029 & 0.020 & $\begin{array}{l}\text { Very } \\
\text { good }\end{array}$ & 4223 & Good \\
\hline D-VII & 0.039 & 0.004 & Excellent & 4261 & Good \\
\hline D-VIII & 0.028 & 0.012 & $\begin{array}{l}\text { Very } \\
\text { good }\end{array}$ & 4279 & Good \\
\hline
\end{tabular}

The results of the air permeability test indicate that all designs show better performance at a longer curing time due to the hydration process of the concrete, and, therefore, to the improvement of its durable and resistant properties, the concrete classifies as very good and excellent considering the research of Torrent \& Ebensperger [23].

Finally, the ultrasonic pulse velocity test demonstrates good concrete quality according to Leslie \& Cheeseman's research [24]. The speed of the wave path is related to the homogeneity and voids that the concrete may present. Therefore, the results obtained are based on the dosage and cement used for the preparation of concrete. 


\section{Chemical Tests}

Like concrete hardened concrete tests, the concrete samples for the present experimental stage correspond to the designs of the second group (see Table II) with variations in the water/cement ratio and Filler Calizo mineral addition to evaluate the influence of these parameters before concentrations of sulfuric acid. The results obtained are presented below:

1) Mass loss: It was determined through the difference in weight between the initial samples, before exposure to $3 \%, 5 \%$ and $7 \%$ concentrations of sulfuric acid, and the samples at the end of each exposure period for a period of 4 and 8 weeks The deterioration of each design evaluated is shown in Fig. 5.

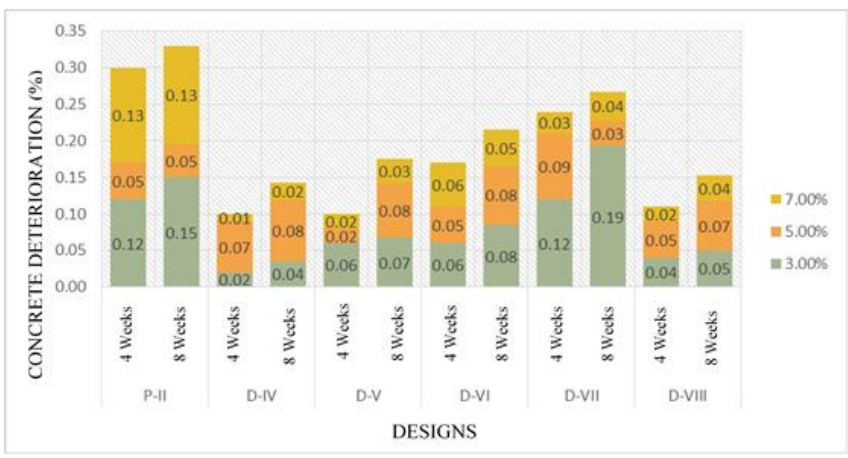

Fig. 5 Concrete deterioration to concentrations of $3 \%, 5 \%$ y $7 \%$ for 4 y 8 exposed weeks

According to the results obtained, the standard design ( $\mathrm{P}-$ II) has the highest percentage of deterioration compared to the other designs evaluated.

Designs D-IV, D-V, and D-VI show an increase in deterioration as the water/cement ratio increases. This is due to the decrease in the cement content and, therefore, a smaller amount of hydrated calcium silicate, a component that constitutes $75 \%$ by weight of the cement and provides the development of strength, hardening, engineering properties and dimensional stability of the concrete [25]. Also, by presenting more water, the cement paste is more porous and less resistant.

The D-VII design with a $10 \%$ Filler Calizo addition compared to the P-II design (15\%), does not show a significant change and the corrosion percentage is almost similar. However, the D-VIII design with 20\% Filler Calizo addition demonstrates lower weight loss and surface deterioration. This result is due to the increase in mineral addition in replacement of cement, whose behavior is described below.

The alkalinity of hardened Portland cement binders, responsible for cementitious properties, can be partially or totally neutralized when sulfuric acid reacts with hydration products such as calcium hydroxide $(\mathrm{CH})$ or hydrated calcium silicates (C-S-H). Besides, sulfuric acid breaks down the cementitious matrix by decalcifying C-S-H. Also, gypsum and ettringite are the main reaction products of cementitious materials subjected to an attack of sulfuric acid, these two products are generally associated with volume expansion, cracking and detachment, and, therefore, loss of dough. Then, a higher cement content implies higher amounts of binders, responsible for the negative reactions in the concrete exposed to sulfuric acid. That is why, the D-VIII design, having more cement replacement by mineral addition, describes a better behavior through weight loss providing cementitious properties necessary to the concrete against deterioration.

2) Visual Analysis: It was carried out after 4 and 8 weeks of immersion in the different concentrations of sulfuric acid. Fig. 6 shows the physical deterioration, which manifests itself in the form of a soft white substance on the surface of all specimens resulting from the breakdown of plaster. These results coincide with the research of Siddique et al [26].

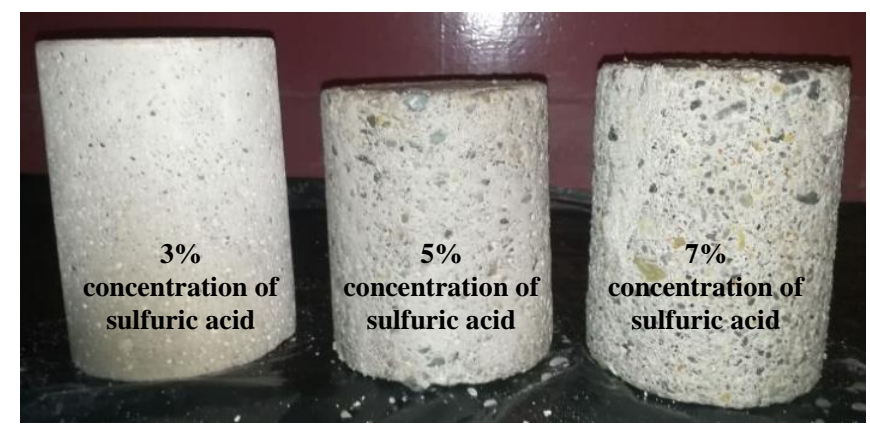

Fig. 6 Panoramic view of the concrete deterioration process

Fig. 7 shows the plan view of the concrete showing the loss of the coating, allowing the aggregates (thickness) to be seen on the surface part of the samples. The right specimen exposed to a 7\% concentration of sulfuric acid shows greater deterioration. On the other hand, the specimen exposed to a lower concentration (left) shows a yellowing in its crosssection. This could be since there is still no obvious reaction of sulfuric acid with the concrete and that, therefore, it has been removed before its decomposition.

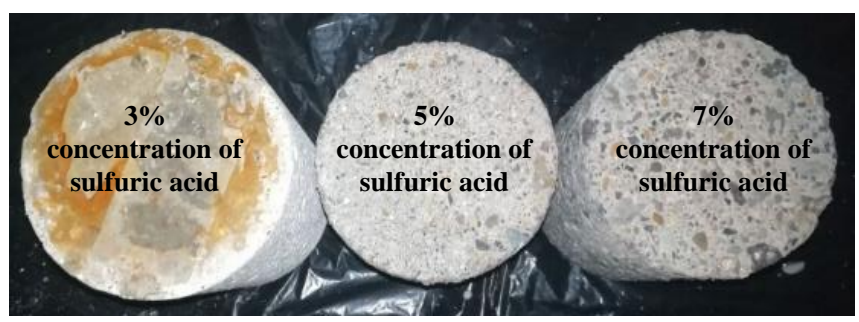

Fig. 7 Base view of the concrete deterioration process.

\section{CONCLUSIONS}

From the microbiological test carried out by exposing the concrete samples in three stages of 20,30, and 40 days before a consortium of bacteria, it is concluded that the Antimicrobial Additive inhibits the growth of bacteria depending on the dosage incorporated; however, it needs an activation time so that it can protect the concrete. Likewise, it is determined that 
the optimum dosage of Antimicrobial Additive for concrete mixtures of $f^{\prime} \mathrm{c} 210 \mathrm{~kg} / \mathrm{cm}^{2}$ is $2.52 \mathrm{l} / \mathrm{m}^{3}$.

From the tests to hardened concrete, water permeability is one of the most important destructive tests that allows to know the quality and penetration of water in the concrete and its results are essential for the design of the steel reinforcement coating. On the other hand, the non-destructive tests made it possible to directly determine the coating quality of the concrete; However, its results are not entirely conclusive.

Before the chemical attack, it is concluded that the Filler Calizo mineral addition demonstrates a better resistance compared to cement due to the lower amount of calcium hydroxide, which implies lower reactions with sulfuric acid that generate decomposition and decalcification of concrete. On the other hand, incorporating cementitious additions such as Filler Calizo in concrete mixtures is an optimal alternative due to its low cost and durability properties that are necessary for aggressive environments. According to the visual analysis of the chemical test, gypsum and lime are the main reaction products of the concrete exposed in sulfuric acid and whose deterioration (\%) corresponds to the total weight loss of these components.

From the results obtained in this investigation, it is concluded that concrete with a low water/cement ratio has better durability properties due to the increase in cement and, therefore, of hydrated calcium silicate, a component that comprises $75 \%$ of the weight of the cement and provides the hardening and strength properties of concrete. Therefore, the antibacterial concrete that demonstrates good behavior against penetration to water, chlorides, weight loss by abrasion and sulfuric acid corresponds to the DV design, which has a compressive strength of $210 \mathrm{~kg} / \mathrm{cm}^{2}$, a water/cement ratio of $0.50,15 \%$ of Filler Calizo mineral addition and $2.521 / \mathrm{m}^{3}$ of Antimicrobial Additive.

\section{REFERENCES}

[1] F. Márquez, Mecanismos de biodeterioro del concreto reforzado. Universidad Francisco de Paula Santander, pp. 118 - 127, 2015.

[2] L. W. Bell, W. E. Shook, \& T. Norris, Mitigating the Corrosion of Concrete Pipe and Manholes. American Society for Testing and Materials, West Conshohocken, 1999.

[3] P. Ramsburg, Preventing sewer corrosion: Precasters take biology lessons to increase the life of concrete sewer systems. American Society for Testing and Materials, West Conshohocken, 2004.

[4] Servicio de Agua Potable y Alcantarillado de Lima (SEDAPAL). Memoria Anual 2014.

[5] BASF. MasterLife AMA 100 Integral antimicrobial concrete admixture, 2016.

[6] Instituto Nacional de Calidad. Norma Técnica Peruana 400.012:2013 AGREGADOS. Analisis granulometrico del agregado fino, grueso y global. Lima: INACAL, 2013.

[7] Instituto Nacional de Calidad. Norma Técnica Peruana 400.022:2013 AGREGADOS. Metodo de ensayo normalizado para la densidad, la densidad relativa (peso epecífico) y absorción del agregado fino. Lima: INACAL, 2013.

[8] Instituto Nacional de Calidad. Norma Técnica Peruana 400.021:2013 AGREGADOS. Método de ensayo normalizado para la densidad, la densidad relativa (peso epecífico) y absorción del agregado grueso. Lima: INACAL, 2013.

[9] Instituto Nacional de Calidad. Norma Técnica Peruana 339.815:2013 AGREGADOS. Método de ensayo normalizado para contenido de humedad total evaporable de agregados por secado. Lima: INACAL, 2013.

[10] Instituto Nacional de Calidad. Norma Técnica Peruana 400.012:2011 AGREGADOS. Método de ensayo normalizado para determinar la masa por unidad de volumen o densidad ("Peso Unitario") y los vacíos en los agregados. Lima: INACAL, 2011.

[11] American Concrete Institute. ACI Committee 211.1-91: Standard Practice for Selecting Proportions for Normal, Heavyweight, and Mass Concrete. Farmington Hills: ACI, 2009.

[12] Instituto Nacional de Calidad. Norma Técnica Peruana 339.035:2015 CONCRETO. Método de ensayo para la medición del asentamiento del concreto de Cemento Portland. Lima: INACAL, 2015.

[13] Instituto Nacional de Calidad. Norma Técnica Peruana 339.184:2013 CONCRETO. Método de ensayo normalizado para determinar la temperatura de mezclas de concreto. Lima: INACAL, 2013.

[14] Instituto Nacional de Calidad. Norma Técnica Peruana 339.046:2008 CONCRETO. Método de ensayo para determinar la densidad (peso unitario), rendimiento y contenido de aire (método gravimétrico) del concreto. Lima: INACAL, 2008.

[15] Instituto Nacional de Calidad. Norma Técnica Peruana 339.082:2017 CONCRETO. Método de ensayo para la determinación del tiempo de fraguado de mezclas por medio de la resistencia a la penetración. Lima: INACAL, 2017.

[16] American Society for Testing and Materials. ASTM C39/C39M-18 Standard Test Method for Compressive Strength of Cylindrical Concrete Specimens. ASTM Internacional, 2018.

[17] American Society for Testing and Materials. ASTM C1202-19 Standard Test Method for Electrical Indication of Concrete's Ability to Resist Chloride Ion Penetration. ASTM Internacional, 2019.

[18] Normalización Española. UNE-EN 12390-8:2009 Ensayos de hormigón endurecido. Profundidad de penetración de agua bajo presión. España: UNE, 2009.

[19] American Society for Testing and Materials. ASTM C944/C944M-12 Standard Test Method for Abrasion Resistance of Concrete or Mortar Surfaces by the Rotating-Cutter Method. ASTM Internacional, 2012.

[20] R. J. Torrent, A two-chamber vacuum cell for measuring the coefficient of permeability to air of the concrete cover on site. Materials and Structures, 25, 358-365. doi: 10.1007/BF02472595, 1992.

[21] American Society for Testing and Materials. ASTM C597-16 Standard Test Method for Pulse Velocity Through Concrete. ASTM Internacional, 2016.

[22] Servicio Nacional de Capacitación para la Industria de la Construcción. Norma Técnica Peruana E.060 Concreto Armado. Lima: SENCICO, 2009.

[23] R. Torrent, \& L. Ebensperger, Measurement of the air permeability of concrete in situ: status quo. ResearchGate. Doi: 10.13140/2.1.3575.1367, 2012.

[24] J. Leslie, \& W. Chessman, An ultrasonic method of studying deterioration and cracking in concrete structures. Journal of American Concrete Institute, Vol. 21, No. 1, pp. 17- 35, 1949.

[25] S. H. Kosmatka, B. Kerkhoff, W. C. Panarese, \& J. Tanesi, Diseño y Control de Mezclas de Concreto. Skokie-Illinois: Portland Cement Association (PCA), 2004.

[26] R. Siddique, \& A. Mehta, Sulfuric acid resistance of fly ash based geopolymer concrete. Construction and Building Materials, 146, 136143,2017 